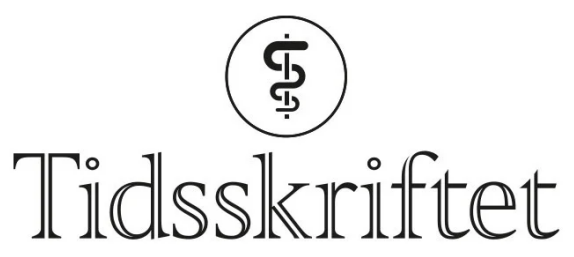

DEN NORSKE LEGEFORENING

\title{
Når det mangler retningslinjer
}

NOE Å LARE AV

\section{ARNE K. ANDREASSEN}

Arne K. Andreassen (f. 1956) er spesialist i kardiologi. Han leder Kardiologisk avdelings program innen hjertesvikt/hjertetransplantasjon og innen pulmonal hypertensjon. Forfatter har fylt ut ICMJE-skjemaet og oppgir ingen interessekonflikter. Email:arne.andreassen@rikshospitalet.no

Oslo universitetssykehus, Rikshospitalet

Under utredning og senere behandling av sjeldnere sykdommer tvinges klinikere til å gå til litteraturen for å få «oppskrifter» og råd som kan redusere deres usikkerhet i møtet med det uvanlige. Fremfor sprikende ekspert- og konsensuserklæringer ønskes klare retningslinjer basert på randomiserte studier, slike som eksisterer for utbredte lidelser. Kamal og medarbeideres kasuistikk illustrerer at disse ikke alltid er innen rekkevidde.

Klassifisering av kardiomyopatier har vært utfordrende, og fortsatt er European Society of Cardiology og American Heart Association uenige om en hensiktsmessig inndeling $(\underline{\mathbf{1}}, \underline{\mathbf{}})$. Dette til tross for at organisasjonene har kommet med stadig flere felles inndelinger og retningslinjer for ulike områder innen kardiologien. Restriktive kardiomyopatier er en heterogen sykdomsgruppe med avleiring i myokard som fellestrekk. Avleiringsmønstrene er forskjellige, med ulike morfologiske og fysiologiske karakteristika. Sterkt varierende klinisk presentasjon og sykdommens sjeldenhet vil medføre hyppig feildiagnostisering. Vedvarende europeisk og amerikansk uenighet om kardiomyopatiinndelingen skaper forvirring heller enn sikrere diagnostikk og behandling.

Hyppigheten av kardial affeksjon ved sarkoidose er usikker. I kliniske studier er insidensen anslått til 5-10\%, ut fra autopsier til 20-6o \%, mens det med MR og PET er påvist hjerteaffeksjon hos nærmere $40 \%$ av pasientene med sarkoidose (3). Klinisk presentasjon med ledningsforstyrrelser, ventrikulære arytmier eller hjertesvikt avhenger av lokalisering, utbredelse og sykdomsaktivitet. Selv om det eksisterer japanske konsensuskriterier for diagnosen kardial sarkoidose, har disse aldri vært prospektivt evaluert (4). . Det er problematisk at det mangler sensitive diagnostiske metoder for en sykdom som kan gi opphav til alt fra symptomfrihet til plutselig hjertedød.

Heller ikke behandlingen av kardial sarkoidose er standardisert. Steroidbehandling er relativt ukontroversielt, men optimal dosering er uavklart. Det er mer usikkert hvorvidt asymptomatiske eller minimalt symptomatiske pasienter i det hele tatt skal behandles. Siden arytmi ikke ble påvist hos den aktuelle pasienten, valgte forfatterne å avstå fra spesifikk antiarytmisk behandling og/eller implantere en defibrillator (Implantable Cardioverter Defibrillator, ICD). Mange kolleger vil st $ø$ tte en slik vurdering, andre ville sett på avgjørelsen som for avventende. Ifølge amerikanske retningslinjer er kardial sarkoidose 
en rimelig indikasjon for å legge inn en ICD (anbefaling klasse IIa) (5). Bakgrunnen er sykdommens progredierende natur. Elektrofysiologisk undersøkelse kan bidra til vurderingen. Pasienter som har spontan eller indusert vedvarende ventrikulær arytmi, synes å ha vesentlig økt risiko for senere livstruende hjertearytmi sammenliknet med pasienter uten utløsbar eller spontan ventrikulær arytmi (므). Men igjen er disse erfaringene bygd på kun én enkelt studie som senere ikke er reprodusert hos asymptomatiske pasienter.

Om pasienten skulle utvikle behov for hjertetransplantasjon, betinget i alvorlig hjertearytmi og/eller økende hjertesvikt, er det ikke sikkert at et slikt tilbud ville bli gitt. Kombinasjonen av kjent systemsykdom og residivfare i transplantatet utgjør relative kontraindikasjoner. Erfaringer fra USA utelukker imidlertid ikke at selekterte pasienter med kardial sarkoidose kan aksepteres (.7.).

\section{LITTERATUR}

1. Elliott P, Andersson B, Arbustini E et al. Classification of the cardiomyopathies: a position statement from the European Society Of Cardiology Working Group on Myocardial and Pericardial Diseases. Eur Heart J 2008; 29: 270-6. [PubMed] [CrossRef]

2. Maron BJ, Towbin JA, Thiene G et al. Contemporary definitions and classification of the cardiomyopathies: an American Heart Association Scientific Statement from the Council on Clinical Cardiology, Heart Failure and Transplantation Committee; Quality of Care and Outcomes Research and Functional Genomics and Translational Biology Interdisciplinary Working Groups; and Council on Epidemiology and Prevention. Circulation 2006;113: 1807-16. [PubMed] [CrossRef]

3. Mehta D, Lubitz SA, Frankel Z et al. Cardiac involvement in patients with sarcoidosis: diagnostic and prognostic value of outpatient testing. Chest 2008; 133: 1426-35. [PubMed] [CrossRef]

4. Soejima K, Yada H. The work-up and management of patients with apparent or subclinical cardiac sarcoidosis: with emphasis on the associated heart rhythm abnormalities. J Cardiovasc Electrophysiol 2009; 20: 578-83. [PubMed] [CrossRef]

5. Epstein AE, DiMarco JP, Ellenbogen KA et al. ACC/AHA/HRS 2008 guidelines for device-based therapy of cardiac rhythm abnormalities: a report of the American College of Cardiology/American Heart Association Task Force on Practice Guidelines (Writing Committee to Revise the ACC/AHA/NASPE 2002 Guideline Update for Implantation of Cardiac Pacemakers and Antiarrhythmia Devices): developed in collaboration with the American Association for Thoracic Surgery and Society of Thoracic Surgeons. Circulation 2008; 117: e350-408. [PubMed] [CrossRef]

6. Mehta D, Mori N, Goldbarg SH et al. Primary prevention of sudden cardiac death in silent cardiac sarcoidosis: role of programmed ventricular stimulation. Circ Arrhythm Electrophysiol 2011; 4: 43-8. [PubMed] [CrossRef]

7. Zaidi AR, Zaidi A, Vaitkus PT. Outcome of heart transplantation in patients with sarcoid cardiomyopathy. J Heart Lung Transplant 2007; 26: 714-7. [PubMed] [CrossRef]

Publisert: 26. juni 2012. Tidsskr Nor Legeforen. DOI:10.4045/tidsskr.12.0436

Mottatt 9.4. 2012 og godkjent 17.4. 2012. Medisinsk redaktør Kristin Viste.

(C) Tidsskrift for Den norske legeforening 2023. Lastet ned fra tidsskriftet.no 26. april 2023. 